\title{
PERUBAHAN KARAKTERISTIK PENGUNJUNG RUANG TERBUKA HIJAU PERKOTAAN SEBAGAI URBAN TOURISM DI TAMAN ALUN-ALUN PACITAN
}

\section{URBAN GREEN OPEN SPACE AS URBAN TOURISM VISITORS CHARACTERISTIC TRANSFORMATION IN TAMAN ALUN-ALUN PACITAN}

\author{
Riswandha Risang Aji ${ }^{a}$, Visilya Faniza ${ }^{b}$ \\ aPerencanaan Wilayah dan Kota; Universitas Islam Bandung; Kota Bandung; riswandha@unisba.ac.id \\ bPerencanaan Wilayah dan Kota; Universitas Diponegoro; Kota Semarang; visilyao9@gmail.com
}

Info Artikel:

- Artikel Masuk: 8 Februari 2021
- Artikel diterima: 25 Juni 2021

\begin{abstract}
ABSTRAK
Pariwisata merupakan sektor yang cukup berkembang di Indonesia maupun di dunia. Pariwisata memiliki multiplier effect yang bisa ikut mengembangkan sektor-sektor lain yang mendukung perkembangan pariwisata itu sendiri. Namun sama seperti sektor-sektor lain, pandemi COVID-19 ini mempengaruhi pariwisata. Wisatawan banyak yang melewatkan masa liburan mereka di rumah karena anjuran pemerintah untuk beraktivitas di rumah. Salah satu jenis pariwisata yang cukup berkembang adalah Urban Tourism. Salah satu Urban Tourism adalah ruang terbuka hijau perkotaan. Ruang terbuka hijau perkotaan yang menjadi objek penelitian ini adalah Taman Alun-Alun Pacitan. Penelitian ini bertujuan untuk menggambarkan perubahan karakteristik wisatawan atau pengunjung dan peran Taman Alun-Alun Pacitan sebagai ruang terbuka hijau sebelum pandemi dan saat pandemi. Metode yang digunakan dalam penelitian ini adalah metode kuantitatif dengan menggunakan kuesioner sebagai alat pengumpulan data dan analisis deskriptif untuk mengolah data. Hasil dari penelitian ini menunjukkan bahwa karakteristik pengunjung mengalami perubahan dari sebelum pandemi dan saat pandemi. Perubahan itu antara lain jarak tempat tinggal pengunjung yang mengerucut menjadi warga yang tinggal di sekitar. Kesimpulan dari penelitian ini adalah Taman Alun-Alun Pacitan mengalami perubahan peran dari yang awalnya berperan sebagai ruang terbuka hijau perkotaan pada periode sebelum pandemi, berubah menjadi lebih dominan berperan sebagai ruang terbuka hijau lingkungan pada saat pandemi.
\end{abstract}

Kata Kunci: Urban Tourism, Pariwisata, Ruang Terbuka Hijau, COVID-19

\begin{abstract}
Tourism is a sector that is quite developed in Indonesia and in the world. Tourism has a multiplier effect that can develop other sectors that support the development of tourism itself. However, just like other sectors, the COVID-19 pandemic is affecting tourism. Many tourists spend their holidays at home because of the government's advice to stay at home. One type of tourism that is quite developed is Urban Tourism. One of Urban Tourism is urban green open space. The urban green open space which is the object of this research is the Taman Alun-Alun Pacitan. This study aims to describe the characteristics transformation of tourists or visitors and the role of Taman Alun-Alun Pacitan as a green open space in the pre-pandemic period and during the pandemic. The method used in this research is quantitative method using a questionnaire as a data collection tool and descriptive analysis to process the data. The results of this study show that the visitor of Taman Alun-Alun Pacitan characteristics have transformed from the pre-pandemic period and during the pandemic. The changes include the distance where visitors live, which narrows down to become residents who live nearby during the pandemic. The conclusion of this research is that Taman Alun-Alun Pacitan has changed its role from initially acting as a city level green open space in the pre-pandemic period, to becoming more dominant as a neighbourhood level green open space during the pandemic.
\end{abstract}

Keyword: Urban Tourism, Green Open Spaces, COVID-19 


\section{PENDAHULUAN}

Pariwisata merupakan salah satu sektor yang menjadi unggulan dalam pembangunan ekonomi regional (Aji dkk, 2018). Pariwisata sebagai sektor unggulan berkembang pesat dalam segi jenis, mulai dari pariwisata yang memanfaatkan sumber daya alam (R. R. Aji, 2020), sumber daya budaya (Santa-Cruz dan López-Guzmán, 2017), hingga kawasan perkotaan (Henderson, 2017). Pemanfaatan kawasan perkotaan sebagai destinasi pariwisata atau Urban Tourism banyak dilakukan di kota-kota besar yang ada di dunia. Hal ini berkaitan dengan sektor pariwisata itu sendiri yang berkembang sebagai pendorong ekonomi (Neckel dkk, 2020). Urban Tourism dapat berupa ruang-ruang publik yang ada di kawasan perkotaan (Caldeira dan Kastenholz, 2018), termasuk kawasan cagar budaya (Buckley, 2018; Esfehani dan Albrecht, 2019) dan ruang terbuka hijau perkotaan (Biernacka dan Kronenberg, 2018; Wolff dkk, 2020).

Ruang terbuka hijau perkotaan sendiri menjadi alternatif masyarakat perkotaan dalam mencari tempat rekreasi (Subramanian dan Jana, 2018). Masyarakat akan mencari ruang publik untuk berekreasi atau sekedar melakukan kegiatan yang berbeda dari rutinitasnya sehari-hari. Taman kota sebagai ruang terbuka hijau sekaligus ruang publik menjadi suatu lokasi yang memiliki nilai atraksi bagi masyarakat yang membutuhkannya (Lahoti dkk, 2019). Namun, dengan adanya pandemi Covid-19, masyarakat dihimbau untuk mengurangi kegiatan dan aktivitasnya di luar rumah (Beck dkk, 2020). Himbauan ini tentu akan menimbulkan perubahan perilaku masyarakat, termasuk karakteristik pengunjung Taman Alun-Alun Pacitan. Penelitian ini bertujuan untuk menggambarkan perubahan karakteristik pengunjung Taman Alun-Alun Pacitan sebelum dan selama masa pandemi Covid-19. Ukuran dalam menentukan perubahannya karakteristik ini adalah aksesibilitas, kepuasan berbasis kebutuhan, kepuasan berbasis penilaian (Fan dkk, 2017; Sun dan Shao, 2020).

Aksesibilitas ruang terbuka hijau merupakan jarak fisik tertentu yang harus ditempuh masyarakat atau pengunjung untuk mencapai ruang terbuka hijau tersebut dari tempat tinggalnya. Aksesibilitas ruang terbuka hijau dibagi menjadi 3 yakni lingkungan, kawasan, dan perkotaan (Fan dkk, 2017). Aksesibilitas skala lingkungan merupakan aksesibilitas untuk pengunjung yang bertempat tinggal dalam radius 300m dari ruang terbuka hijau. Aksesibilitas skala kawasan merupakan aksesibilitas untuk pengunjung yang bertempat tinggal dalam radius $2000 \mathrm{~m}$ dari ruang terbuka hijau. Aksesibilitas skala perkotaan merupakan aksesibilitas untuk pengunjung yang bertempat tinggal dalam radius 5000m dari ruang terbuka hijau.

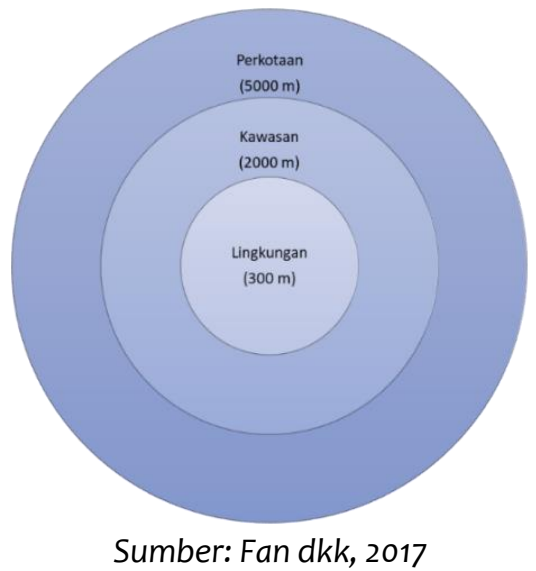

Gambar 1. Diagram Aksesibilitas Ruang Terbuka Hijau

\section{DATA DAN METODE}

Metode yang digunakan dalam penelitian ini adalah metode kuantitatif. Metode pengumpulan data yang dilakukan adalah kuesioner. Pengambilan data dilakukan pada 2 periode, yakni pada Januari 2020 dan pada Agustus 2020. Perbedaan periode ini bertujuan untuk menggambarkan perbedaan karakteristik 
pengunjung pada saat sebelum pandemi (Januari 2020) dan pada saat pandemi (Agustus 2020). Selain berdasarkan periode, pengunjung juga dilihat berdasarkan waktu berkunjungnya yakni awal pekan (weekday) pada hari Senin - Jumat dan akhir pekan (weekend) pada hari Sabtu - Minggu. Hal ini digunakan untuk melihat perbedaan pemanfaatan ruang terbuka hijau Taman Alun-Alun Pacitan. Informasi mengenai hal tersebut didapatkan menggunakan kuesioner yang disebar ke pengunjung pada masing-masing periode menggunakan sampel acak. Masing-masing periode diambil sampel acak sebanyak 100 pengunjung. Selanjutnya berdasarkan hasil kuesioner tersebut dilakukan analisis kualitatif mengenai pengembangan ruang terbuka hijau lain berdasarkan fungsi pemanfaatannya.

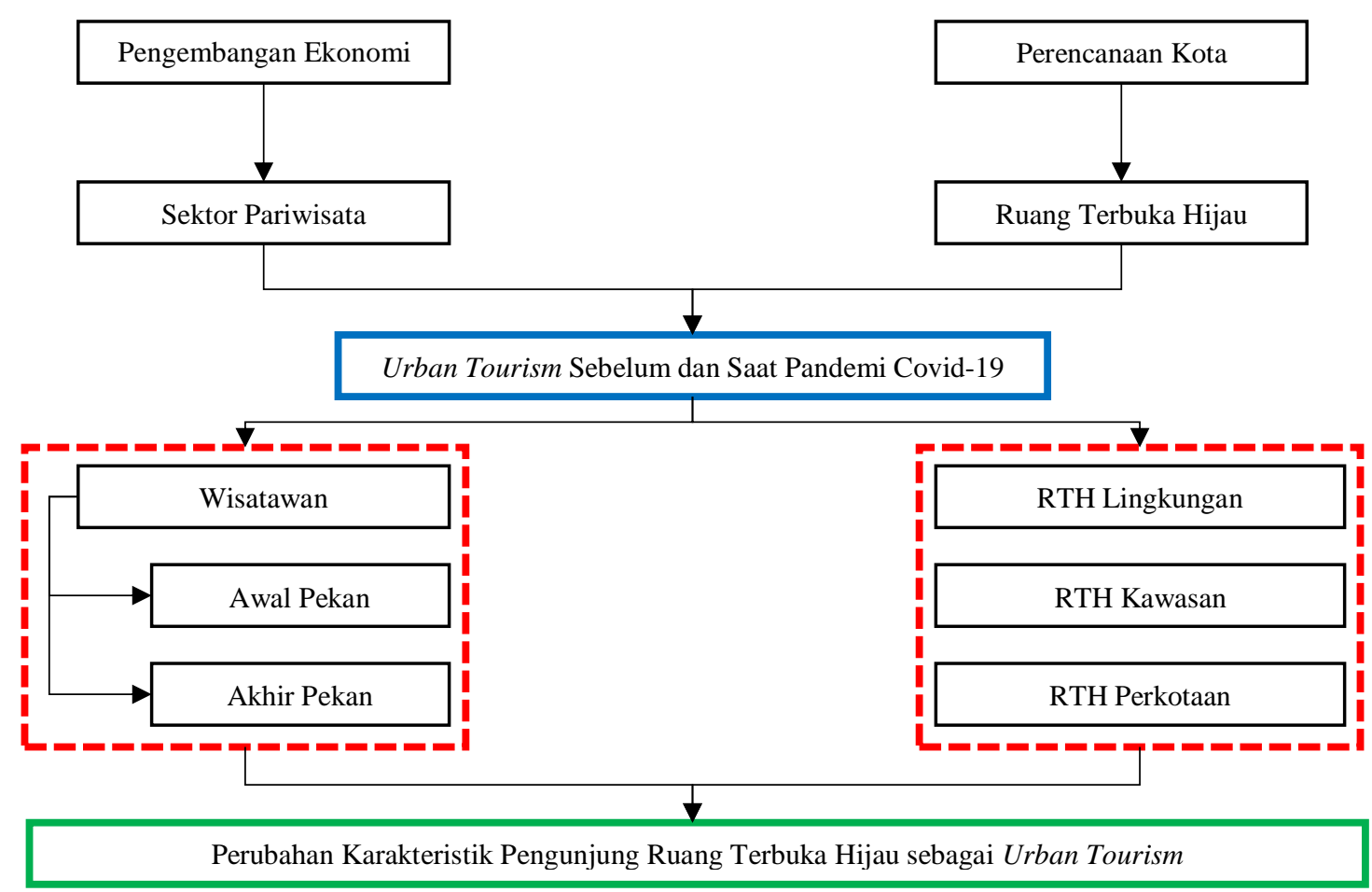

Sumber: Penulis, 2020

Gambar 2. Kerangka Alur Penelitian

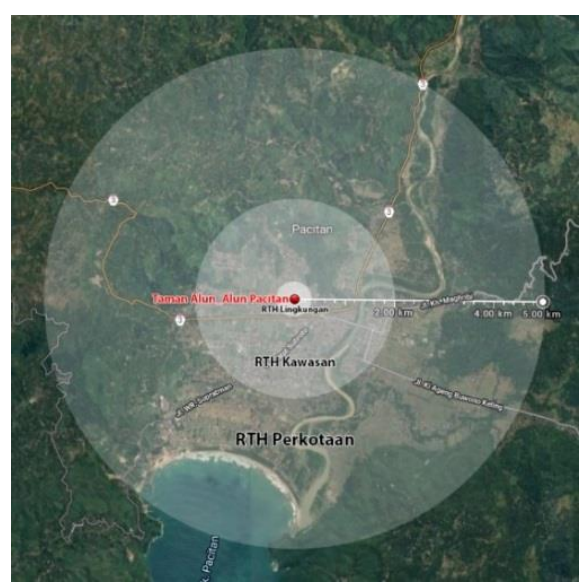

Sumber: Penulis, 2020

Gambar 3. Peta Aksesibilitas Taman Alun-Alun Pacitan

Penelitian ini terfokus pada Taman Alun-Alun Pacitan yang berfungsi sebagai ruang terbuka hijau perkotaan. Penelitian ini di lakukan di dua periode waktu sebelum dan sesudah pandemi terhadap 
pengunjung Taman Alun-Alun Pacitan. Lokasi taman ini tepat berada di titik okm Pacitan sehingga radius aksesibilitas menuju ke taman ini mencangkup seluruh wilayah permukiman. Peta di atas menunjukkan Aksesibilitas Taman Alun-Alun Pacitan.

\section{HASIL DAN PEMBAHASAN}

Karakteristik pengunjung dilihat dari jarak tempat tinggal ke lokasi ruang terbuka hijau. Jarak tempuh dari tempat tinggal pengunjung menuju ke Taman Alun-Alun Pacitan menunjukkan peran taman kota ini sebagai jenis ruang terbuka hijau lingkungan, kawasan, atau perkotaan. Hal ini bisa digunakan sebagai acuan dalam pemenuhan kebutuhan pengunjung.

Karakteristik pengunjung Taman Alun-Alun Pacitan saat awal pekan pada periode sebelum pandemi didominasi oleh masyarakat yang bertempat tinggal di sekitar ruang terbuka hijau tersebut (radius 300m). Taman Alun-Alun Pacitan pada periode sebelum pandemi di awal pekan berperan sebagai ruang terbuka hijau lingkungan sebesar $86 \%$, ruang terbuka hijau kawasan sebesar $10 \%$, dan ruang terbuka hijau perkotaan sebesar 4\%. Sama halnya dengan kegiatan lain, pandemi Covid-19 mempengaruhi trend kunjungan masyarakat ke ruang terbuka hijau. Persentase kunjungan sebelum dan semasa pandemi di awal pekan dapat dilihat pada gambar berikut.

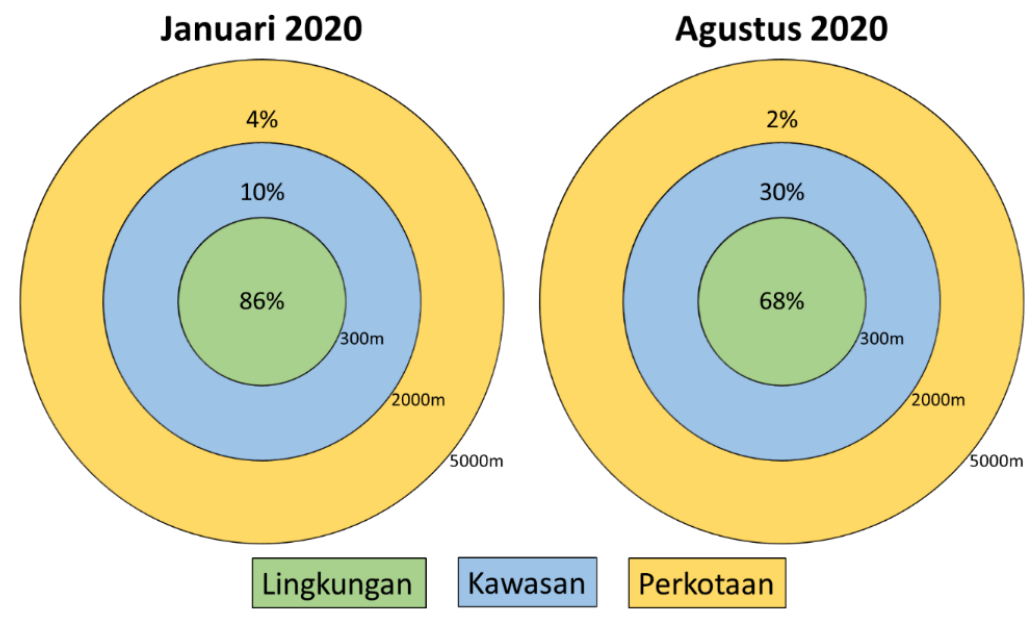

Sumber: Penulis, 2020

Gambar 4. Angka Aksesibilitas Ruang Terbuka Hijau Sebelum (Januari 2020) dan Saat Pandemi (Agustus 2020) di Awal Pekan

Karakteristik pengunjung pada periode sebelum dan saat pandemi di awal pekan didominasi oleh pengunjung yang bertempat tinggal di sekitar taman. Meski demikian tampak penurunan angka pada ruang terbuka hijau lingkungan sebesar $18 \%$. Sama halnya dengan ruang terbuka hijau perkotaan yang mengalami penurunan sebesar $2 \%$. Hal ini diasumsikan terjadi karena adanya himbauan pemerintah untuk mengurangi aktivitas di luar rumah guna mengurangi laju penyebaran virus Covid-19.

Pada kategori ruang terbuka hijau kawasan, kunjungan mengalami kenaikan sebesar $20 \%$ dimana pengunjung merupakan masyarakat yang tinggal di radius $300 \mathrm{~m}$ hingga $2 \mathrm{~km}$ dari lokasi. Munculnya trend yang datang dari bentuk-bentuk himbauan pemerintah untuk mencegah virus Covid-19 juga mempengaruhi aksesibilitas masyarakat. Kegiatan pendidikan dan pekerjaan yang dilaksanakan di rumah menunjukan ketersediaan waktu yang lebih besar untuk beraktivitas diluar ruangan yang tidak hanya terjadi di akhir pekan. Salah satu himbauan tersebut adalah rutin berolahraga. Ruang terbuka hijau menjadi trend lokasi dimana masyarakat yang tinggal di radius ruang terbuka kawasan meningkat karena memiliki jarak tempuh yang ideal untuk berolahraga. Kunjungan didominasi oleh warga lokal atau lingkungan (Higgins-Desbiolles, 2020). Perbandingan aksesibilitas taman alun-alun pada awal pekan dapat dilihat pada grafik berikut. 


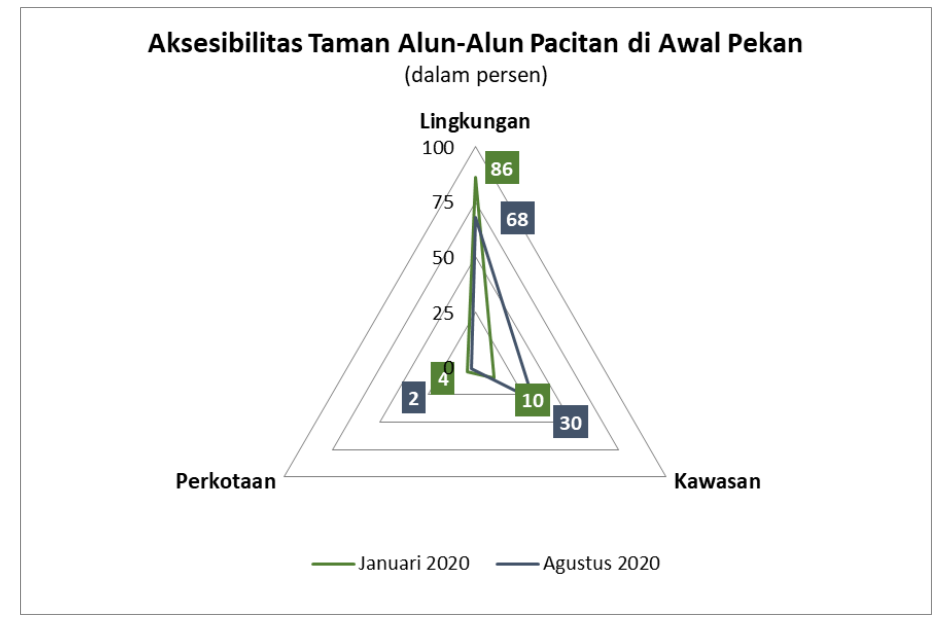

Sumber: Penulis, 2020

Gambar 5. Perbandingan Aksesibilitas Ruang Terbuka Hijau Sebelum (Januari 2020) dan Saat Pandemi (Agustus 2020) di Awal Pekan

Sebelum pandemi Covid-19, terdapat berbagai kegiatan yang diselenggarakan di Taman Alun-Alun Pacitan pada akhir pekan. Kegiatan-kegiatan tersebut antara lain car free day, senam, dan pusat kuliner. Pengunjung banyak yang datang menggunakan kendaraan pribadi sehingga karakteristik pengunjung cenderung merata. Kegiatan akhir pekan ini menjadikan karakteristik pengunjung Taman Alun-Alun Pacitan pada periode sebelum pandemi di akhir pekan menunjukkan hasil yang berbeda dengan karakteristik awal pekan. Taman Alun-Alun Pacitan pada periode sebelum pandemi di akhir pekan berperan sebagai ruang terbuka hijau lingkungan sebesar 30\%, ruang terbuka hijau kawasan sebesar $27 \%$, dan ruang terbuka hijau perkotaan sebesar $43 \%$. Setelah merebaknya pandemi Covid-19, kondisi yang menyebabkan kegiatan akhir pekan tidak dapat terlaksana merubah karakteristik pengunjung. Persentase kunjungan sebelum dan semasa pandemi di akhir pekan dapat dilihat pada gambar berikut.
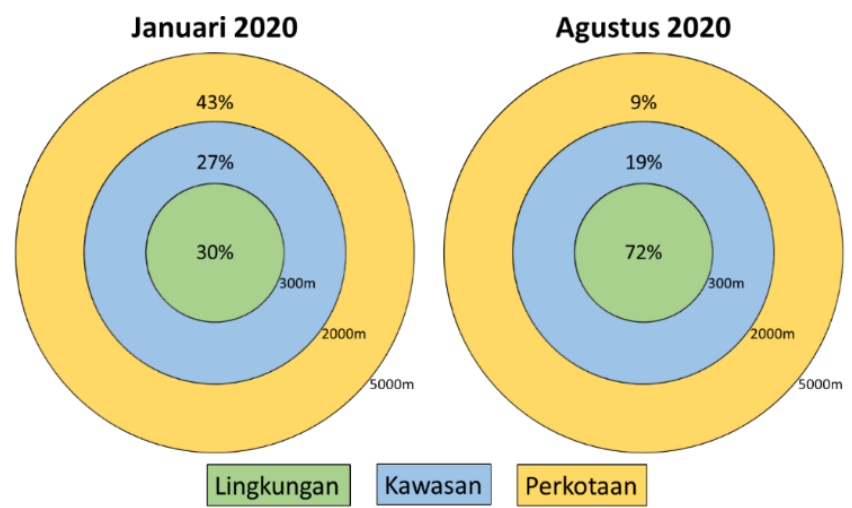

Sumber: Penulis, 2020

Gambar 6. Angka Aksesibilitas Ruang Terbuka Hijau Sebelum (Januari 2020) dan Saat Pandemi (Agustus 2020) di Akhir Pekan

Karakteristik pengunjung di akhir pekan berubah setelah adanya pandemi Covid-19. Saat pandemi kegiatan-kegiatan yang biasanya diselenggarakan di Taman Alun-Alun seperti car free day, senam, dan pusat kuliner tidak lagi diselenggarakan. Pemerintah perlu memperhatikan hal yang berkaitan dengan ekonomi seperti ini untuk menyelamatkan industri pariwisata (Bakar \& Rosbi, 2020). Hal ini menyebabkan pengunjung Taman Alun-Alun Pacitan kebanyakan masyarakat yang tinggal di sekitar yang berkunjung untuk relaksasi dan melepas penat dari kegiatan work from home. Pembatasan pergerakan atau mobilitas inilah yang 
mengurangi pengunjung jauh seperti yang dari level kawasan dan perkotaan (Gössling, Scott, \& Hall, 2020). Dampak tersebut dapat dilihat dari peran taman sebagai ruang terbuka hijau lingkungan dengan pengunjung yang berasal dari wilayah sekitar taman mengalami kenaikan sebesar $42 \%$, sementara peran taman sebagai ruang terbuka kawasan dan perkotaan mengalami penurunan yang cukup signifikan. Perubahan tersebut dapat dilihat pada grafik berikut.

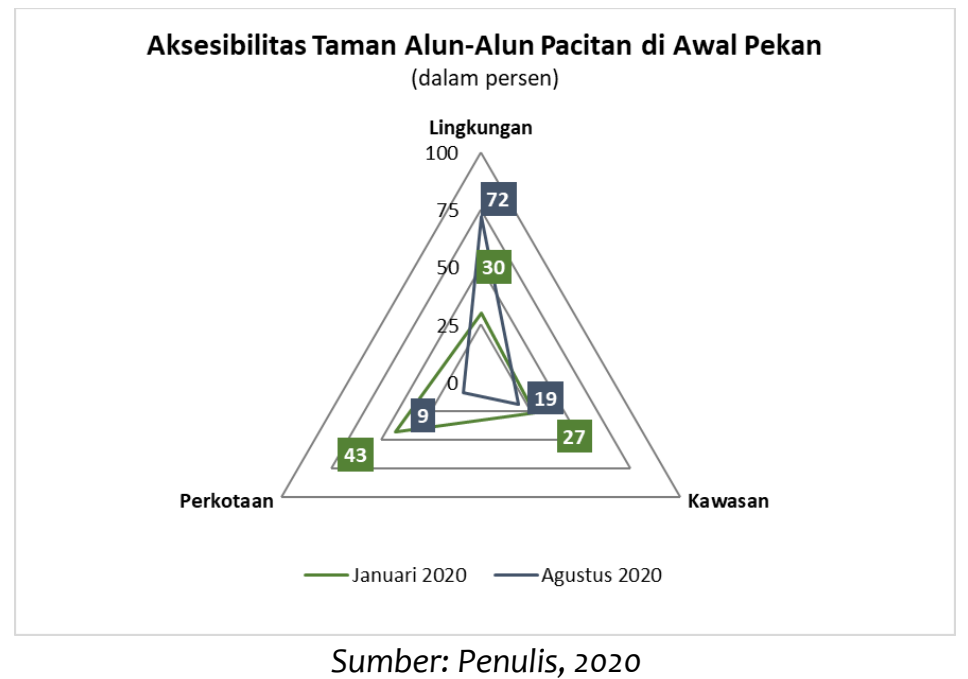

Gambar 7. Perbandingan Aksesibilitas Ruang Terbuka Hijau Sebelum (Januari 2020) dan Saat Pandemi (Agustus 2020) di Akhir Pekan

\section{KESIMPULAN}

Karakteristik pengunjung Taman Alun-Alun Pacitan pada periode sebelum pandemi di awal pekan kebanyakan merupakan masyarakat yang tinggal di sekitar. Pada periode pandemi pengunjung masih didominasi oleh masyarakat yang tinggal di sekitar, namun terdapat peningkatan pengunjung dari masyarakat yang tinggal di radius menengah. Taman Alun-Alun Pacitan memiliki peran dominan sebagai ruang terbuka hijau lingkungan di periode awal pekan baik sebelum pandemi maupun saat pandemi.

Pengunjung Taman Alun-Alun Pacitan mengalami perubahan karakteristik pada periode akhir pekan dari sebelum pandemi dan saat pandemi. Karakteristik pengunjung Taman Alun-Alun Pacitan sebelum pandemi kebanyakan merupakan masyarakat yang tinggal jauh dari taman. Variasi pengunjung lebih merata pada periode akhir pekan sebelum pandemi. Perubahan terjadi saat pandemi di mana pengunjung Taman Alun-Alun Pacitan pada periode akhir pekan mengalami perubahan menjadi didominasi oleh masyarakat yang tinggal di sekitar. Taman Alun-Alun Pacitan mengalami perubahan peran dari yang awalnya berperan sebagai ruang terbuka hijau perkotaan pada periode sebelum pandemi, berubah menjadi lebih dominan berperan sebagai ruang terbuka hijau lingkungan pada saat pandemi.

\section{PERNYATAAN RESMI}

Terima kasih kepada Program Studi Perencanaan Wilayah dan Kota Universitas Islam Bandung atas dukungannya terhadap publikasi penelitian ini.

\section{REFERENSI}

Aji, R. R. (2020). Tourism social entrepreneurship in community-based tourism: A case study of Pentingsari tourism village. IOP Conference Series: Earth and Environmental Science, 447(1). https://doi.org/10.1088/17551315/447/1/012009

Aji, Riswandha Risang, Pramono, R. W. D., \& Rahmi, D. H. (2018). Kontribusi Sektor Pariwisata Terhadap Ekonomi 
Aji, Faniza/ Jurnal Pembangunan Wilayah dan Kota, Vol. 17, No. 3, 2021, $334-340$

Doi: $10.14710 / p w k . v 17 i 3.36534$

Wilayah Di Provinsi Jawa Timur. Jurnal Planoearth, 3(2), 57-62. https://doi.org/10.31764/jpe.v3i2.600

Bakar, N. A., \& Rosbi, S. (2020). Effect of Coronavirus disease (COVID-19) to tourism industry. International Journal of Advanced Engineering Research and Science, 7(4), 189-193. https://doi.org/10.22161/ijaers.74.23

Beck, M. J., Hensher, D. A., \& Wei, E. (2020). Slowly coming out of COVID-19 restrictions in Australia: Implications for working from home and commuting trips by car and public transport. Journal of Transport Geography, 88(September), 102846. https://doi.org/10.1016/j.jtrangeo.2020.102846

Biernacka, M., \& Kronenberg, J. (2018). Classification of institutional barriers affecting the availability, accessibility and attractiveness of urban green spaces. Urban Forestry and Urban Greening, 36(August), 22-33. https://doi.org/10.1016/j.ufug.2018.09.007

Buckley, R. (2018). Tourism and Natural World Heritage: A Complicated Relationship. Journal of Travel Research, 57(5), 563-578. https://doi.org/10.1177/0047287517713723

Caldeira, A. M., \& Kastenholz, E. (2018). Tourists' spatial behaviour in urban destinations: The effect of prior destination experience. Journal of Vacation Marketing, 24(3), 247-26o. https://doi.org/10.1177/1356766717706102

Esfehani, M. H., \& Albrecht, J. N. (2019). Planning for Intangible Cultural Heritage in Tourism: Challenges and Implications. Journal of Hospitality and Tourism Research, 43(7), 980-1001. https://doi.org/10.1177/1096348019840789

Fan, P., Xu, L., Yue, W., \& Chen, J. (2017). Accessibility of public urban green space in an urban periphery: The case of Shanghai. Landscape and Urban Planning, 165, 177-192. https://doi.org/10.1016/j.landurbplan.2016.11.007

Gössling, S., Scott, D., \& Hall, C. M. (2020). Pandemics, tourism and global change: a rapid assessment of COVID-19. Journal of Sustainable Tourism, 29(1), 1-20. https://doi.org/10.1080/09669582.2020.1758708

Henderson, J. (2017). Global cities, Tokyo, urban tourism. International Journal of Tourism Cities, 3(2), $143-157$. https://doi.org/10.1108/IJTC-01-2017-0006

Higgins-Desbiolles, F. (2020). Socialising tourism for social and ecological justice after COVID-19. Tourism Geographies, 22(3), 610-623. https://doi.org/10.1080/14616688.2020.1757748

Lahoti, S., Lahoti, A., \& Saito, O. (2019). Benchmark assessment of recreational public Urban Green space provisions: A case of typical urbanizing Indian City, Nagpur. Urban Forestry and Urban Greening, 44(February), 126424. https://doi.org/10.1016/j.ufug.2019.126424

Neckel, A., Da Silva, J. L., Saraiva, P. P., Kujawa, H. A., Araldi, J., \& Paladini, E. P. (2020). Estimation of the economic value of urban parks in Brazil, the case of the City of Passo Fundo. Journal of Cleaner Production, 264, 121369. https://doi.org/10.1016/j.jclepro.2020.121369

Santa-Cruz, F. G., \& López-Guzmán, T. (2017). Culture, tourism and World Heritage Sites. Tourism Management Perspectives, 24(August), 111-116. https://doi.org/10.1016/j.tmp.2017.08.004

Subramanian, D., \& Jana, A. (2018). Urban Forestry \& Urban Greening Assessing urban recreational open spaces for the elderly: A case of three Indian cities. Urban Forestry \& Urban Greening, 35(August), 115-128. https://doi.org/10.1016/j.ufug.2018.08.015

Sun, Y., \& Shao, Y. (2020). Measuring Visitor Satisfaction toward Peri-urban Green and Open Spaces Based on Social Media Data. Urban Forestry and Urban Greening. https://doi.org/10.1016/j.ufug.2020.126709

Wolff, M., Scheuer, S., \& Haase, D. (2020). Looking beyond boundaries: Revisiting the rural-urban interface of Green Space Accessibility in Europe. Ecological Indicators, 113(January). https://doi.org/10.1016/j.ecolind.2020.106245 